\title{
Efektivitas massage frirage dan kombinasi back massage-stretching untuk penyembuhan nyeri pinggang
}

\author{
Ardi Utomo *, BM. Wara Kushartanti \\ Program Studi Ilmu Keolahragaan, Program Pascasarjana, Universitas Negeri Yogyakarta. \\ Jalan Colombo No. 1, Karangmalang, Yogyakarta, 55281, Indonesia \\ * Corresponding Author. E-mail: ardiutomo2308@ gmail.com \\ Received: 25 July 2018; Revised: 25 October 2018; Accepted: 20 March 2019
}

\begin{abstract}
Abstrak
Penelitian ini bertujuan untuk mengungkapkan: (1) pengaruh jenis perlakuan massage frirage dan kombinasi back massage-stretching untuk penyembuhan nyeri pinggang, (2) pengaruh kondisi cedera akut dan kronis terhadap penyembuhan nyeri pinggang, dan (3) interaksi jenis perlakuan dengan kondisi cedera terhadap penyembuhan nyeri pinggang yang ditunjukkan peningkatan ROM pinggang pada pasien Physical Therapy Clinic Fakultas Ilmu Keolahragaan Universitas Negeri Yogyakarta (PTC FIK UNY). Penelitian ini adalah eksperimen dengan desain faktorial 2 x 2, dengan menggunakan tes awal dan tes akhir. Subjek penelitian ini adalah 40 orang pasien klinik PTC yang mengalami nyeri pinggang kronis maupun akut akibat aktivitas kerja yang berjenis kelamin laki-laki usia 25-50 tahun. Instrumen pengumpulan data pengukuran terhadap ROM menggunakan goniometer dan tingkat nyeri menggunakan skala nyeri rating scale. Analisis data menggunakan uji ANOVA dua jalur. Hasil penelitian adalah sebagai berikut. (1) Terdapat pengaruh jenis perlakuan massage frirage dan kombinasi back massage-stretching untuk penyembuhan nyeri pinggang yang ditunjukkan peningkatan ROM pinggang pada pasien PTC FIK UNY. (2) Terdapat pengaruh kondisi cedera akut dan kronis terhadap penyembuhan nyeri pinggang yang ditunjukkan peningkatan ROM pinggang pada pasien PTC FIK UNY. (3) Terdapat interaksi jenis perlakuan dengan kondisi cedera terhadap penyembuhan nyeri pinggang yang ditunjukkan peningkatan ROM pinggang pada pasien PTC FIK UNY. Hasil analisis diketahui masase frirage lebih baik untuk menyembuhkan nyeri pinggang akut sedangkan kombinasi back massage-stretching lebih baik untuk menyembuhkan nyeri pinggang kronis.
\end{abstract}

Kata Kunci: Masase frirage, kombinasi back massage-stretching, nyeri pinggang

\section{The effectiveness of frirage massage and back massage stretching in the healing pain}

\begin{abstract}
This study aims to reveal: (1) the effect of frirage massage treatment and combination of back massagestretching on healing waist pain, (2) the effect of acute and chronic injury conditions on the healing of low back pain, and (3) the interaction of the type of treatment and injury condition to the healing of waist pain as shown by the improvement of ROM pain the patients of Physical Therapy Clinic (PTC) FIK UNY. This research was an experiment with the factorial design $2 \times 2$, by using preliminary test (pre-test) and final test (post-test). The subjects were 40 patients of PTC who experienced chronic and acute waist pain due to work activities, whose ages ranged from 25 to 50 years old. The data collection instrument was a measurement test. The data analysis used the two-way ANOVA Test. The results were as follows. (1) There was an effect of frirage massage treatment type and the combination of back massage-stretching on healing waist pain as shown by the improvement of ROM pain. (2) There an effect of acute and chronic injury condition on the healing of waist pain as shown by the increase of ROM pain. (3) There was an interaction between the type of treatment and the condition of injury on the healing of waist pain as shown by the increase of ROM pain. Keywords: Frirage massage, combination of back massage-stretching, back pain
\end{abstract}

How to Cite: Utomo, A., \& Kushartanti, B. (2019). Efektivitas massage frirage dan kombinasi back massagestretching untuk penyembuhan nyeri pinggang pasien physical therapy clinic. Jurnal Keolahragaan, 7(1), 43-56. doi:https://doi.org/10.21831/jk.v7i1.20549

do

https://doi.org/10.21831/jk.v7i1.20549 


\section{PENDAHULUAN}

Perkembangan dunia kesehatan di era modern saat ini tidak terlepas dari kemajuan ilmu pengetahuan dan teknologi yang penuh dengan inovasi sebagai salah satu program untuk keberhasilan dalam penanganan kesehatan. Dunia kesehatan yang terkait dengan medis sangat menunjang untuk program penyembuhan yang efektif dan efesien bagi berbagai macam keluhan dan penyakit. Keluhan pada gangguan kesehatan juga telah didukung oleh peran pengobatan tradisional seperti pengobatan tradisional dengan ramuan (Jennifer \& Saptutyningsih, 2015) dan pengobatan tradisional dengan pemijatan (masase) (Sugiharto, Supriyono, \& Rasyad, 2016). Pengobatan tradisional dengan pemberian ramuan herbal dan pemijatan telah diatur oleh Undang-Undang Republik Indonesia nomor 36 tahun 2009 tantang kesehatan pasal 1 dan Undang-Undang Republik Indonesia nomor 23 tahun 1992 tentang penyelengaraan pengobatan tradisional (Presiden Republik Indonesia, 1992, 2009). Di Indonesia perkembangan pengobatan khususnya pemijatan (masase) telah berkembang sebagai usaha pengobatan alternatif untuk pencegahan secara prepentif dan kuratif (Syafi'i, 2019).

Perkembangan pengobatan alternatif di Indonesia beragam macam dan jenisnya antara lain: masase tradisional Indonesia terdiri dari Masase Jawa, Masase Bali, dan masase terapi cedera olahraga (masase frirage), sedangkan masase tradisional dari luar negeri seperti Shiatsu, Thai Massage, Japannase Massage, Swedis Massage, refleksiologi dan akupresur yang berkembang dengan usaha yang diatur oleh Undang-Undang Republik Indonesia nomor 10 tahun 2009 tentang kepariwisataan dan UndangUndang Republik Indonesia nomor 52 tahun 2012 tentang sertifikasi kompetensi dan sertifikasi usaha di bidang pariwisata seperti lab klinik terapi fisik sebagai pendukung pariwisata kesehatan dan pengobatan alternatif bagi penderita yang mengalami keluhan cedera (Presiden Republik Indonesia, 2009, 2012).

Klinik terapi fisik (physical therapy clinic) merupakan tempat pengobatan tradisional modern yang terdapat di Fakultas Ilmu Keolahragaan Universitas Negeri Yogyakarta. Pengobatan tradisional modern berupa pemijatan (masase) yang dikembangkan oleh lab terapi fisik Fakultas Ilmu Keolahragaan hasil dari perkuliahan dan pengambilan konsentrasi terapi masase yang tertuang dalam kurikulum di Program Studi
Ilmu Keolahragaan. Lab terapi fisik sebagai salah satu program tridarma perguruan tinggi yang mengembangkan pengabdian pada masyarakat melalui pemberian pelayanan berupa masase terapi, baik untuk relaksasi maupun untuk penanganan cedera ringan. Pelayanan masase yang diberikan untuk masyarakat yang berkunjung di lab terapi fisik bermacam macam keluhan cedera yang dialami seperti hasil penelitian Graha \& Priyonohadi (2012) menunjukkan bahwa terdapat sepuluh macam cedera anggota gerak tubuh yang dialami pasien cidera, yaitu cedera leher, bahu, siku, pergelangan tangan, jari tangan, pinggang, panggul, lutut, engkel, dan jari kaki. Dari sepuluh macam cedera tersebut cedera pinggang merupakan cedera yang paling sering dialami pasien yang berkunjung ke pusat pelayanan Physical Therapy Clinic Fakultas Ilmu Keolahragaan Universitas Negeri Yogyakarta (PTC FIK UNY) dengan membawa hasil ronsen yang telah di indikasi dari medis dinyatakan mengalami keluhan sakit pinggang. Diperkuat oleh hasil penelitian (Tana \& Delima, 2013) bahwa nyeri pinggang pada data paramedis di beberapa rumah sakit di Jakarta banyak mengalam nyeri pinggang dengan menunjukan porsi nyeri pinggang dalam 1 tahun terakhir 28,5\% dari 382 orang. Nyeri pinggang pada paramedis yang memindahkan pasien ditempat tidur sebesar 55\% dan saat memindahkan pasien ke/dari kursi roda 23,9\%. Nyeri pinggang yang mengalami kambuhan lebih dari satu kali dalam setahun $90,8 \%$, yang mengalami rasa nyeri lebih buruk dari sebelumnya $11 \%$ dan yang mencari pengobatan ke dokter $43,1 \%$. Prosentase nyeri pinggang lebih tinggi pada usia 40 tahun ke atas dibandingkan umur kurang dari 40 tahun.

Nyeri menjadi suatu masalah yang mempengaruhi seseorang dalam menjalani aktivitas sehari-hari salah satunya nyeri pinggang. Nyeri pinggang atau keluhan yang berasal dari berbagai macam jaringan dalam struktur vertebra. Hasil penelitian menyatakan sekitar $45 \%$ kasus nyeri pinggang berasal pada daerah discus, sedangkan $13 \%$ nyeri berasal dari gangguan di sacroilliaca joint, dan antara $15 \%$ sampai $40 \%$ nyeri berasal dari facet joint (Kallewaard et al., 2010). Nyeri pinggang dapat diklasifikasikan menjadi dua yaitu nyeri pinggang akut maupun nyeri pinggang kronis. Nyeri Akut yang tajam, dalam dan langsung maupun tiba-tiba. Seorang tidak dapat beristirahat dengan tenang dan setiap gerak bagian punggung bawah atau pinggang yang terkena bertambah nyeri yang terjadi selama kurang dari 8 minggu. Sedangkan nyeri kronis yaitu nyeri 
yang terus menerus dan tidak berkurang meskipun pikiran bisa teralihkan dengan sesuatu hal yang mempesona. Kadang-kadang nyeri berulang tetapi untuk kekambuhan ditimbulkan untuk aktivitas fisik yang sepele.

Dalam sebuah survey yang dilakukan oleh (Kambodji, 2002) di beberapa negara, orang yang menderita low back pain atau nyeri pinggang pada saat itu adalah 17-30\% dalam sebulan mencapai $19-43 \%$ dan yang pernah menderita nyeri pinggang semasa hidupnya mencapai $80 \%$. Berdasarkan jenis kelamin perempuan lebih banyak (70,3\%) dibandingkan laki-laki $(57,4 \%)$. Angka kejadian nyeri pinggang atau low back pain pada pekerja sangat bervariasi, tergantung pada tipe pekerjaannya. Di wilayah Amerika Serikat, sepertiga pekerja mengalami sakit pinggang. Sekitar 150 juta hari kerja hilang setiap tahunnya yang melibatkan $17 \%$ dari seluruh pekerja di Amerika (Kambodji, 2002). Pekerja yang mempunyai resiko paling tinggi untuk penderita sakit pinggang adalah yang sering mengangkat beban berat, membungkuk, dan mendorong seperti pekerja kontruksi, pekerja pertambangan, dan petani.

Pada kejadian nyeri pinggang atau low back pain kebanyakan orang penderitanya atau pasien tidak mengakibatkan kecacatan, dari 50\% penderita nyeri pinggang membaik dalam satu minggu, sementara lebih dari $90 \%$ merasa lebih baik dalam 8 minggu. Sisanya sekitar 7\%-10\% mengalami keluhan yang berlanjut sampai lebih dari 6 bulan. Dalam upaya penyembuhan nyeri pinggang seseorang banyak melakukan hal agar nyeri pinggang yang dalami berkurang bahkan tidak kambuh. Penyembuhan adalah proses usaha penanganan dan pemulihan keluhan maupun cedera yang timbul karena berbagai macam faktor penyebab.

Dalam hal metode penyembuhan ada macam-macam bentuk terapi yang dapat digunakan untuk usaha penyembuhan seperti luka, cedera, dan beberapa penyakit. Adapun macam-macam bentuk teknik penyembuhan yaitu terapi latihan, manual terapi, thermotherapy, coldtherapy, electrotherapy, iontophoresis, traksi, dan terapi masase (Arovah, 2010). Masase frirage dan back masase adalah bentuk dari terapi masase yang banyak di cari masyarakat sebagai metode penyembuhan pada cedera salah satunya nyeri pada pinggang.

Masase frirage adalah suatu teknik gabungan dari friction (gerusan) dan efflurage (gosokan) yang dilakukan dalam gerakan memijat atau pijatan (Graha \& Priyonoadi, 2009).
Manfaat dari masase frirage sendiri dapat membantu untuk peyembuhan setelah penanganan medis maupun sebelum penanganan medis sebagai salah satu pencegahan dan perawatan tubuh dari cedera, penyakit, kelelahan dan perawatan kulit. Selain masase frirage dalam penyembuhan cedera seseorang ada yang menggunakan teknik back masase- streching.

Back massage adalah sebuah stimulasi kulit dengan cara menggunakan gerakan efflurage pada bagian punggung bawah atau pinggang yang dilakukan untuk menghilangkan nyeri, bekerja dengan cara mendorong pelepasan endorfin, sehingga memblok transmisi stimulus nyeri. Stretching adalah peregangan otot yang diperlukan dan digunakan baik untuk orang sehat atau sakit untuk mengulur, melenturkan atau menambah fleksibilitas otot-otot yang dianggap bermasalah (Lestari, Sukarja, \& Suari, 2018).

Hasil pengamatan di Physical Therapy Clinic FIK UNY pasien yang berkunjung mengeluhkan sakit pinggang. Keluhan sakit pinggang yang dialami pasien terapi fisik diakibatkan aktivitas olahraga, aktivitas sehari hari dan akibat terjatuh atau kecelakaan. Dari uraian permasalahan yang telah dijelaskan, maka dari pernyataan hasil penelitian tersebut, peneliti ingin mengungkap lebih dalam tentang nyeri pinggang baik kronis maupun akut sebagai kebaruan penelitian ini menggunakan masase frirage dan kombinasi back massage-stretching sebagai penyembuhan nyeri pingggang pasien PTC FIK UNY yang belum diketahui secara statistik untuk penyembuhannya.

\section{METODE}

Jenis penelitian yang digunakan dalam penelitian ini adalah jenis eksperimen dengan menggunakan rancangan 2 X 2 (Tabel 1). Waktu yang dilakukan dalam penelitian ini dimulai pada bulan Agustus sampai Oktober 2017, sedangkan tempat penelitian berlangsung di lab Physical Therapy Clinic Fakultas Ilmu Keolahragaan Universitas Negeri Yogyakarta, yang berada di Daerah Istimewa Yogyakarta.

Subjek dalam penelitian ini ditetapkan oleh peneliti dengan teknik quota sampling yang berjumlah 40 orang pasien yang berjenis kelamin laki-laki dan berusia 25-50 tahun dan memenuhi kriteria sebagai sempel penelitian kemudian digolongkan menjadi 4 kelompok yang disesuaikan dengan kriteria yang ditentukan oleh peneliti berdasarkan kondisi cedera (akut kronis) dan tretmen yang diberikan (massase frirage dan kombinasi back massage-stretching). 
Penelitian ini memakai desain eksperimen dua faktor dan dua level, faktor pertama variabel manipulatif adalah treatment masase dan faktor kedua variabel atributif yaitu kondisi nyeri pinggang. Treatmen masase disini terdiri dari masase frirage dan kombinasi back massagestretching, sedangkan variabel atributif terdiri dari kondisi nyeri pinggang akut dan kondisi nyeri pinggang kronis.

Tabel 1. Rancangan Faktorial 2x2.

\begin{tabular}{lll}
$\begin{array}{r}\text { Treatmen } \\
\text { masase } \\
\text { (A) }\end{array}$ & $\begin{array}{c}\text { Masase } \\
\text { Frirage (A1) }\end{array}$ & $\begin{array}{c}\text { Back massage- } \\
\text { Stretching (A2) }\end{array}$ \\
$\begin{array}{l}\text { Nyeri } \\
\text { pinggang } \\
\text { (B) }\end{array}$ & & \\
\hline Akut (B1) & A1.B1 & A2.B1 \\
Kronis (B2) & A1.B2 & A2.B2 \\
\hline
\end{tabular}

Berdasarkan Tabel 1 diperoleh keterangan bahwa, A1 adalah Masase Frirage. A2 adalah Back Massage-Stretching. B1 adalah nyeri pinggang akut. Dan B2 adalah nyeri pinggang kronis. Sedangkan $A_{1} B_{1}$ merupakan kelompok yang mengalami nyeri pinggang akut diberikan terapi masase dengan massage frirage. $\mathrm{A}_{2} \mathrm{~B}_{1}$ merupakan Kelompok yang mengalami nyeri pinggang akut diberikan dengan kombinasi back massage-stretching. $\mathrm{A}_{1} \mathrm{~B}_{2}$ merupakan Kelompok yang mengalami nyeri pinggang kronis diberikan terapi masase dengan massage frirage. Serta $\mathrm{A}_{2} \mathrm{~B}_{2}$ merupakan Kelompok yang mengalami nyeri pinggang kronis diberikan dengan kombinasi back massage-stretching

Jenis data yang diperoleh dalam penelitian ini adalah data kuantitatif, data kuantitatif diperoleh dari pengukuran ROM sendi pinggang dan skala nyeri pada pinggang. Instrumen dalam penelitian ini menggunakan rating sacle untuk mengetahui tanda peradangan merah, nyeri, bengkak, dan panas serta menggunakan jangka busur atau goniometer untuk mengetahui penurunan fungsi dengan mengukur ROM sendi.

Data yang dikumpulkan dalam penelitian ini adalah data yang diperoleh dengan menggunakan tes dan pengukuran pada pasien physical clinic therapy yang mengalami nyeri pinggang akut maupun kronis. Metode pengumpulan data ini menggunakan dua tahap, tahap awal dan tahap akhir yaitu sebelum diberi perlakuan masase frirage dan kombinasi back massage-stretching serta sesudah diberi perlakuan masase frirage dan kombinasi back massage-stretching. Tahap awal dalam pengumpulan data ini yaitu, responden terlebih dahulu mengisi angket catatan medis sebelum diberikan perlakuan masase frirage dan kombinasi back massage-stretching dan membagi responden menjadi beberapa kelompok sesuai kriteria yg telah di tentukan oleh peneliti yang mana dilihat dari catatan medis yang telah diisi oleh responden. Setelah diberikan perlakuan masase frirage dan kombinasi back massagestretching responden akan diukur kembali perasaan nyeri dan ROM dengan mengisi angket catatan medis kembali. Perbandingan hasil pengisian kedua angket (pretest-posttest) tersebut akan menunjukan pengaruh masase frirage dan kombinasi back massage-stretching.

Teknik analisis data yang digunakan dalam penelitian ini menggunakan ANOVA dua jalur (ANOVA two-way) pada taraf signifikansi $\alpha=$ 0,05 . Mengingat analisis data penelitian dilakukan dengan mengunakan ANOVA, maka sebelum sampai pada pemanfaatan ANOVA dua jalur (ANOVA two-way) maka perlu dilakukan uji persyaratan yaitu meliputi uji normalitas, dan uji homogenitas varians.

\section{HASIL DAN PEMBAHASAN}

Data Penelitian ini bertujuan mengkaji tentang efektivitas massage frirage dan kombinasi back massage-stretching untuk penyembuhan nyeri pinggang (low back pain) pasien klinik terapi fisik FIK UNY. Data penelitian dianalisis secara deskriptif dengan tujuan untuk memberikan gambaran data penelitian serta untuk mempermudah penyajian data penelitian.

Umur responden penelitian diantara rentang 25 tahun sampai 50 tahun dengan ratarata umur 34,22 tahun dan standar deviasi sebesar 5,87. Distribusi umur responden terdistribusi seperti terlihat pada Tabel 2.

Tabel 2. Deskripsi Umur Subyek Penelitian

\begin{tabular}{rcc}
\hline Umur & Frekuensi & Persentase $(\%)$ \\
\hline $26-30$ th & 15 & 37,5 \\
$31-35$ th & 10 & 25,0 \\
$36-40$ th & 8 & 20,0 \\
$41-46$ th & 7 & 17,5 \\
Total & 40 & 100,0 \\
\hline
\end{tabular}

Berdasarkan analisis diketahui dari 40 responden dalam penelitian ini rata-rata berumur 34,22 dengan standar deviasi sebesar 5,87. Distriburi umur dalam Tabel 4, diketahui bahwa umur 26-30 tahun (37,5\%) lebih banyak dari umur 31-35 tahun (25\%). Distribusi frekuensi umur secara lebih jelas dapat dilihat pada Gambar 1. 
Jurnal Keolahragaan 7 (1), 2019 - 47

Ardi Utomo, BM. Wara Kushartanti

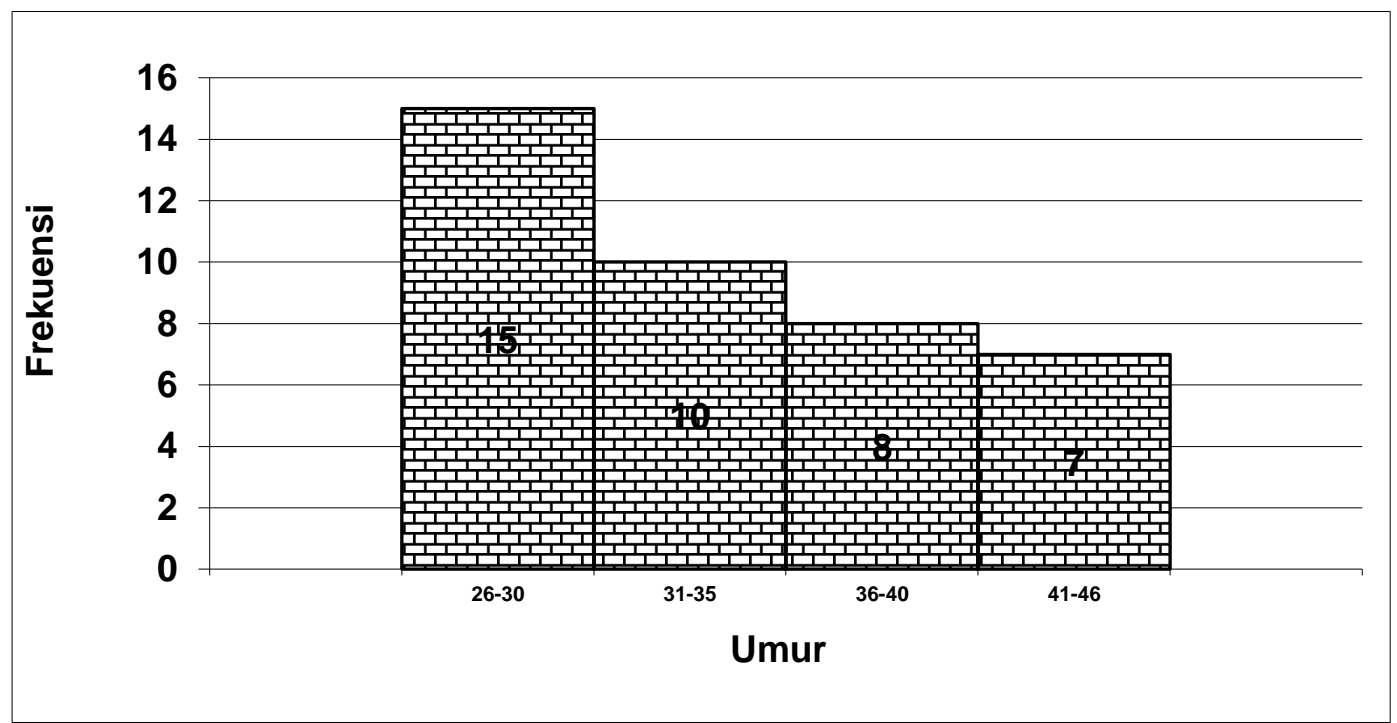

Gambar 1. Distribusi Umur Subjek Penelitian

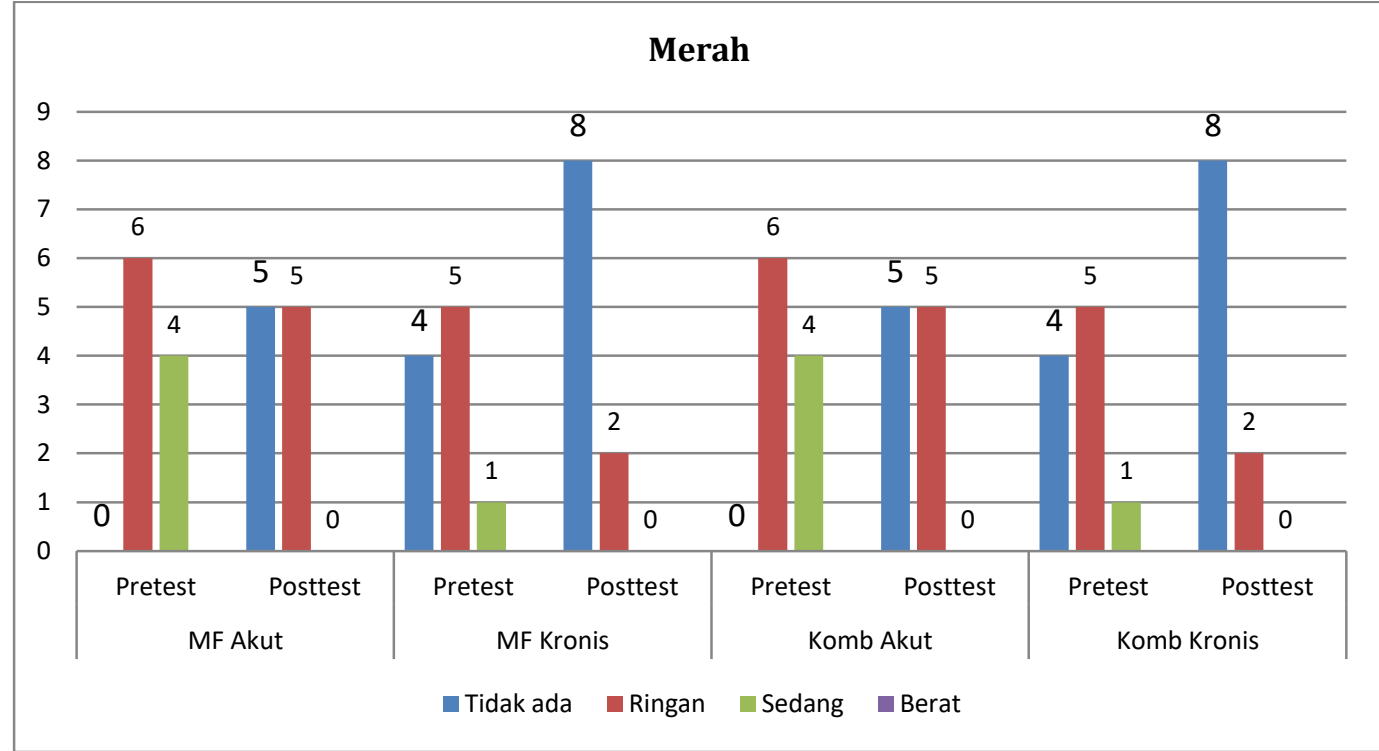

Gambar 2. Tanda Radang Merah

Tabel 3. Deskripsi Tanda Radang Merah Pretest

\begin{tabular}{lcccccccc}
\hline \multirow{2}{*}{ Merah } & \multicolumn{2}{c}{ MF Akut } & \multicolumn{2}{c}{ MF Kronis } & \multicolumn{2}{c}{ Komb Akut } & \multicolumn{2}{c}{ Komb Kronis } \\
\cline { 2 - 9 } \multicolumn{1}{c}{} & $\mathrm{F}$ & $\%$ & $\mathrm{~F}$ & $\%$ & $\mathrm{f}$ & $\%$ & $\mathrm{f}$ & $\%$ \\
\hline Tidak ada & 0 & 0,0 & 4 & 40,0 & 0 & 0,0 & 4 & 40,0 \\
Ringan & 6 & 60,0 & 5 & 50,0 & 6 & 60,0 & 5 & 50,0 \\
Sedang & 4 & 40,0 & 1 & 10,0 & 4 & 40,0 & 1 & 10,0 \\
Berat & 0 & 0,0 & 0 & 0,0 & 0 & 0,0 & 0 & 0,0 \\
\multicolumn{1}{c}{ Total } & 10 & 100,0 & 10 & 100,0 & 10 & 100,0 & 10 & 100,0 \\
\hline
\end{tabular}

Tabel 4. Deskripsi Tanda Radang Merah Posttest

\begin{tabular}{lcccccccc}
\hline \multirow{2}{*}{ Merah } & \multicolumn{2}{c}{ MF Akut } & \multicolumn{2}{c}{ MF Kronis } & \multicolumn{2}{c}{ Komb Akut } & \multicolumn{2}{c}{ Komb Kronis } \\
\cline { 2 - 10 } & $\mathrm{F}$ & $\%$ & $\mathrm{~F}$ & $\%$ & $\mathrm{f}$ & $\%$ & $\mathrm{~F}$ & $\%$ \\
\hline Tidak ada & 5 & 50,0 & 8 & 80,0 & 5 & 50,0 & 8 & 80,0 \\
Ringan & 5 & 50,0 & 2 & 20,0 & 5 & 50,0 & 2 & 20,0 \\
Sedang & 0 & 0,0 & 0 & 0,0 & 0 & 0,0 & 0 & 0,0 \\
Berat & 0 & 0,0 & 0 & 0,0 & 0 & 0,0 & 0 & 0,0 \\
$\quad$ Total & 10 & 100,0 & 10 & 100,0 & 10 & 100,0 & 10 & 100,0 \\
\hline
\end{tabular}


Tanda radang diamati sebanyak 2 kali yaitu saat pretest dan posttest setelah mendapatkan perlakuan. Tanda radang meliputi merah, panas dan bengkak. Hasil analisis deskriptif tanda radang dapat dilihat pada Gambar 2.

\section{Merah}

Berdasarkan Tabel 3, diketahui tanda radang merah saat pretest kelompok MF akut sebagian besar kategori ringan $(60 \%)$. Pada kelompok MF kronis sebagian besar ringan (50\%). Pada kelompok kombinasi akut sebagian besar ringan $(60 \%)$ dan pada kelompok kombinasi kronis sebagian besar ringan $(50 \%)$.

Berdasarkan Tabel 4, diketahui tanda radang merah saat posttest kelompok MF akut sebagian besar kategori tidak ada (50\%). Pada kelompok MF kronis sebagian besar tidak ada (80\%). Pada kelompok kombinasi akut sebagian besar tidak ada (50\%) dan pada kelompok kombinasi kronis sebagian besar tidak ada (80\%).
Secara lebih jelas tanda radang merah dapat dilihat pada Gambar 2.

\section{Panas}

Berdasarkan Tabel 5, diketahui tanda radang panas saat pretest kelompok MF akut sebagian besar kategori sedang (60\%). Pada kelompok MF kronis sebagian besar ringan $(60 \%)$. Pada kelompok kombinasi akut sebagian besar ringan $(60 \%)$ dan pada kelompok kombinasi kronis sebagian besar ringan (60\%).

Berdasarkan Tabel 5, diketahui tanda radang panas saat posttest kelompok MF akut seluruhnya kategori ringan (100\%). Pada kelompok MF kronis sebagian besar ringan (80\%). Pada kelompok kombinasi akut seluruhnya ringan $(100 \%)$ dan pada kelompok kombinasi kronis sebagian besar ringan (80\%). Secara lebih jelas tanda radang panas dapat dilihat pada Gambar 3.

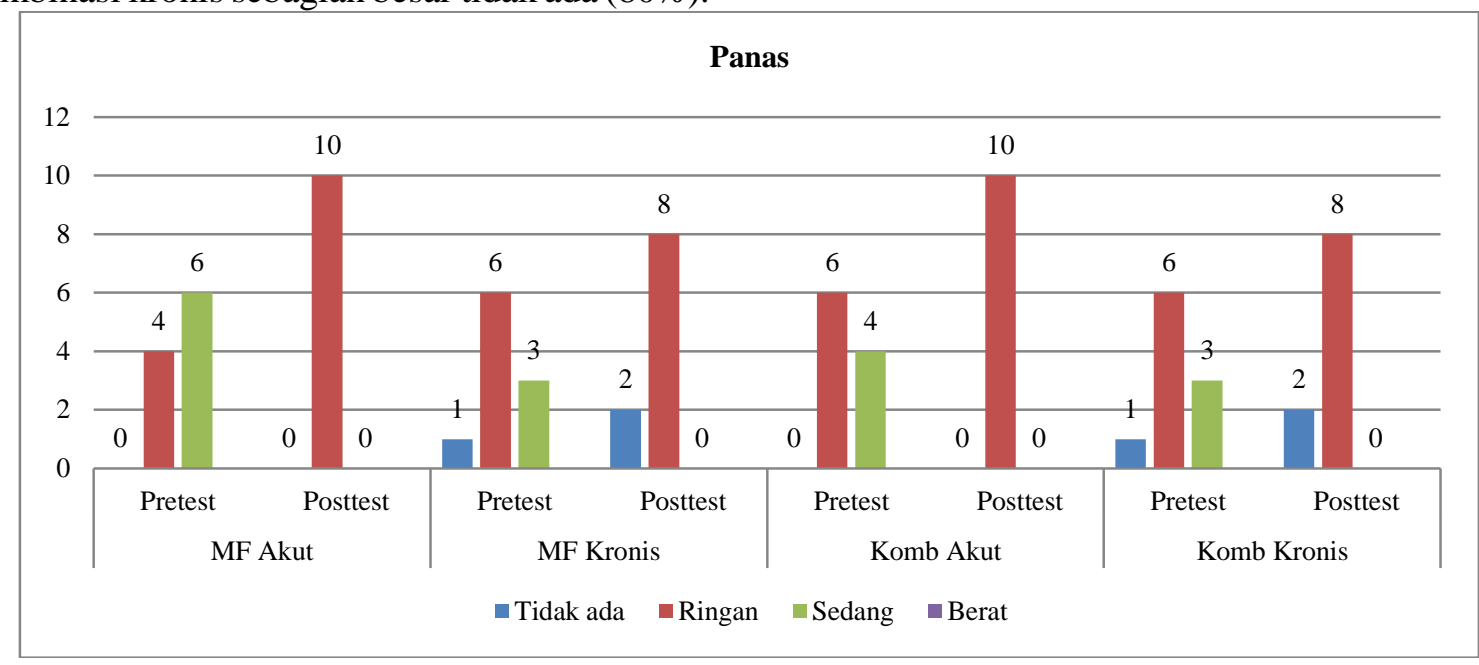

Gambar 3. Tanda Radang Panas

Tabel 5. Deskripsi Tanda Radang Panas Pretest

\begin{tabular}{lcccccccc}
\hline \multirow{2}{*}{ Panas } & \multicolumn{2}{c}{ MF Akut } & \multicolumn{2}{c}{ MF Kronis } & \multicolumn{2}{c}{ Komb Akut } & \multicolumn{2}{c}{ Komb Kronis } \\
\cline { 2 - 9 } & $\mathrm{F}$ & $\%$ & $\mathrm{~F}$ & $\%$ & $\mathrm{~F}$ & $\%$ & $\mathrm{f}$ & $\%$ \\
\hline Tidak ada & 0 & 0,0 & 1 & 10,0 & 0 & 0,0 & 1 & 10,0 \\
Ringan & 4 & 40,0 & 6 & 60,0 & 6 & 60,0 & 6 & 60,0 \\
Sedang & 6 & 60,0 & 3 & 30,0 & 4 & 40,0 & 3 & 30,0 \\
Berat & 0 & 0,0 & 0 & 0,0 & 0 & 0,0 & 0 & 0,0 \\
$\quad$ Total & 10 & 100,0 & 10 & 100,0 & 10 & 100,0 & 10 & 100,0 \\
\hline
\end{tabular}

Tabel 6. Deskripsi Tanda Radang Panas Posttest

\begin{tabular}{lcccccccc}
\hline \multirow{2}{*}{ Panas } & \multicolumn{2}{c}{ MF Akut } & \multicolumn{2}{c}{ MF Kronis } & \multicolumn{2}{c}{ Komb Akut } & \multicolumn{2}{c}{ Komb Kronis } \\
\cline { 2 - 9 } & $\mathrm{F}$ & $\%$ & $\mathrm{~F}$ & $\%$ & $\mathrm{f}$ & $\%$ & $\mathrm{f}$ & $\%$ \\
\hline Tidak ada & 0 & 0,0 & 2 & 20,0 & 0 & 0,0 & 2 & 20,0 \\
Ringan & 10 & 100,0 & 8 & 80,0 & 10 & 100,0 & 8 & 80,0 \\
Sedang & 0 & 0,0 & 0 & 0,0 & 0 & 0,0 & 0 & 0,0 \\
Berat & 0 & 0,0 & 0 & 0,0 & 0 & 0,0 & 0 & 0,0 \\
\multicolumn{1}{c}{ Total } & 10 & 100,0 & 10 & 100,0 & 10 & 100,0 & 10 & 100,0 \\
\hline
\end{tabular}




\section{Bengkak}

Berdasarkan Tabel 7, diketahui tanda radang bengkak saat pretest kelompok MF akut sebagian besar kategori sedang (90\%). Pada kelompok MF kronis sebagian besar ringan (50\%). Pada kelompok kombinasi akut sebagian besar sedang (90\%) dan pada kelompok kombinasi kronis sebagian besar ringan (50\%).

Berdasarkan Tabel 8, diketahui tanda radang bengkak saat posttest kelompok MF akut sebagian besar kategori ringan (90\%). Pada kelompok MF kronis sebagian besar tidak ada $(50 \%)$. Pada kelompok kombinasi akut sebagian besar ringan $(90 \%)$ dan pada kelompok kombinasi kronis sebagian besar tidak ada (50\%). Secara lebih jelas tanda radang bengkak dapat dilihat pada Gambar 4.

Hasil analisis deskriptif pada data masingmasing kelompok penelitian dapat dilihat pada Tabel 8. Berikut ini adalah data pengukuran hasil perbandingan nilai rerata peningkatan ROM pada masing-masing kelompok perlakuan.

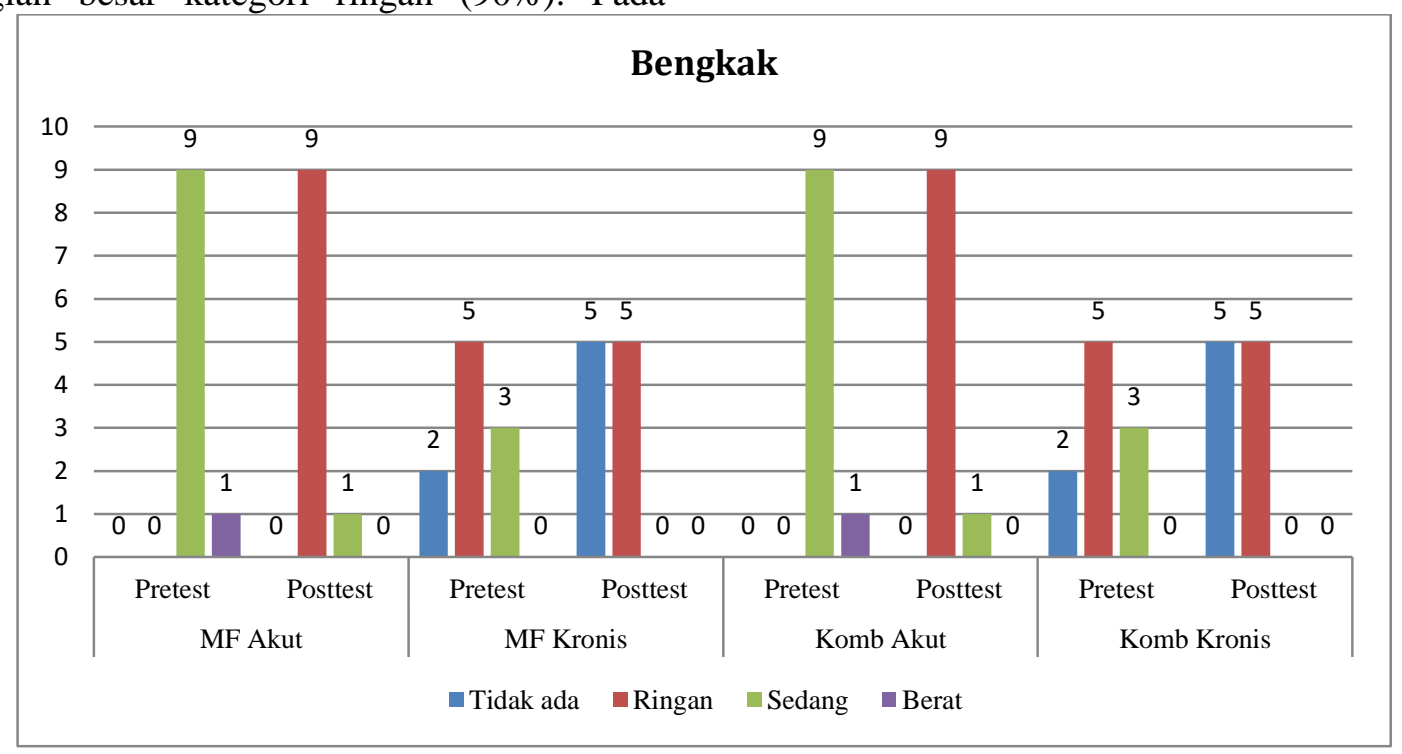

Gambar 4. Tanda Radang Panas

Tabel 7. Deskripsi Tanda Radang Bengkak Pretest

\begin{tabular}{lcccccccc}
\hline \multirow{2}{*}{ Bengkak } & \multicolumn{2}{c}{ MF Akut } & \multicolumn{2}{c}{ MF Kronis } & \multicolumn{2}{c}{ Komb Akut } & \multicolumn{2}{c}{ Komb Kronis } \\
\cline { 2 - 8 } & $\mathrm{F}$ & $\%$ & $\mathrm{~F}$ & $\%$ & $\mathrm{f}$ & $\%$ & $\mathrm{f}$ & $\%$ \\
\hline Tidak ada & 0 & 0,0 & 2 & 20,0 & 0 & 0,0 & 2 & 20,0 \\
Ringan & 0 & 0,0 & 5 & 50,0 & 0 & 0,0 & 5 & 50,0 \\
Sedang & 9 & 90,0 & 3 & 30,0 & 9 & 90,0 & 3 & 30,0 \\
Berat & 1 & 10,0 & 0 & 0,0 & 1 & 10,0 & 0 & 0,0 \\
\multicolumn{1}{c}{ Total } & 10 & 100,0 & 10 & 100,0 & 10 & 100,0 & 10 & 100,0 \\
\hline
\end{tabular}

Tabel 8. Deskripsi Tanda Radang Bengkak Posttest

\begin{tabular}{lcccccccc}
\hline \multirow{2}{*}{ Bengkak } & \multicolumn{2}{c}{ MF Akut } & \multicolumn{2}{c}{ MF Kronis } & \multicolumn{2}{c}{ Komb Akut } & \multicolumn{2}{c}{ Komb Kronis } \\
\cline { 2 - 9 } & $\mathrm{F}$ & $\%$ & $\mathrm{~F}$ & $\%$ & $\mathrm{~F}$ & $\%$ & $\mathrm{f}$ & $\%$ \\
\hline Tidak ada & 0 & 0,0 & 5 & 50,0 & 0 & 0,0 & 5 & 50,0 \\
Ringan & 9 & 90,0 & 5 & 50,0 & 9 & 90,0 & 5 & 50,0 \\
Sedang & 1 & 10,0 & 0 & 0,0 & 1 & 10,0 & 0 & 0,0 \\
Berat & 0 & 0,0 & 0 & 0,0 & 0 & 0,0 & 0 & 0,0 \\
\multicolumn{1}{c}{ Total } & 10 & 100,0 & 10 & 100,0 & 10 & 100,0 & 10 & 100,0 \\
\hline
\end{tabular}

Tabel 9. Perbandingan Delta Rerata Pada Masing-masing Kelompok

\begin{tabular}{ccccccc}
\hline Kel & Fleksi & Ekstensi & Rotasi kanan & Rotasi kiri & Lateral fleksi kanan & Lateral fleksi kiri \\
\hline$\left(\mathrm{A}_{1} \mathrm{~B}_{1}\right)$ & $\mathbf{1 4 , 7}$ & $\mathbf{1 1 , 5}$ & $\mathbf{1 0 , 1}$ & $\mathbf{1 0 , 6}$ & $\mathbf{1 1}$ & $\mathbf{1 0 , 6}$ \\
$\left(\mathrm{A}_{1} \mathrm{~B}_{2}\right)$ & 9,8 & 9,5 & 9,6 & 9,7 & 8,9 & 9,7 \\
$\left(\mathrm{~A}_{2} \mathrm{~B}_{1}\right)$ & 9,3 & 6,6 & 7,4 & 7 & 7,5 & 8,1 \\
$\left(\mathrm{~A}_{2} \mathrm{~B}_{2}\right)$ & $\mathbf{9 , 9}$ & $\mathbf{1 0 , 1}$ & $\mathbf{9 , 9}$ & $\mathbf{1 0}$ & $\mathbf{9 , 6}$ & $\mathbf{9 , 9}$ \\
\hline
\end{tabular}


Berdasarkan Tabel 8 diketahui pada data fleksi peningkatan tertinggi pada kelompok masase frirage-nyeri akut $\left(A_{1} B_{1}\right)$ sebesar 14,7. Pada data ekstensi peningkatan tertinggi pada kelompok masase frirage-nyeri akut $\left(\mathrm{A}_{1} \mathrm{~B}_{1}\right)$ sebesar 11,5. Pada data rotasi kanan peningkatan tertinggi pada kelompok masase frirage-nyeri akut $\left(A_{1} B_{1}\right)$ sebesar 10,1. Pada data rotasi kiri peningkatan tertinggi pada kelompok masase frirage-nyeri akut $\left(\mathrm{A}_{1} \mathrm{~B}_{1}\right)$ sebesar 10,6. Pada data lateral fleksi kanan peningkatan tertinggi pada kelompok masase frirage-nyeri akut $\left(\mathrm{A}_{1} \mathrm{~B}_{1}\right)$ sebesar 11. Pada data lateral fleksi kiri peningkatan tertinggi pada kelompok masase frirage-nyeri akut $\left(\mathrm{A}_{1} \mathrm{~B}_{1}\right)$ sebesar 10.6.
Perbandingan delta rerata pada masingmasing kelompok secara lebih jelas dapat dilihat pada Gambar 6. Hasil analisis diskriptif tingkat penurunan nyeri pada pinggang dapat dilihat pada tabel 9. Berdasarkan Tabel di 9, diketahui penurunan tingkat nyeri pada nyeri akut lebih baik pada kelompok yang diberikan masase frirage sebesar 4,3. Tingkat nyeri pada nyeri kronis lebih baik pada kelompok yang diberikan masase frirage sebesar 3,8. perbandingan tingkat nyeri saat pretest dan posttest pada masingmasing kelompok perlakuan dapat dilihat pada Gambar 7.

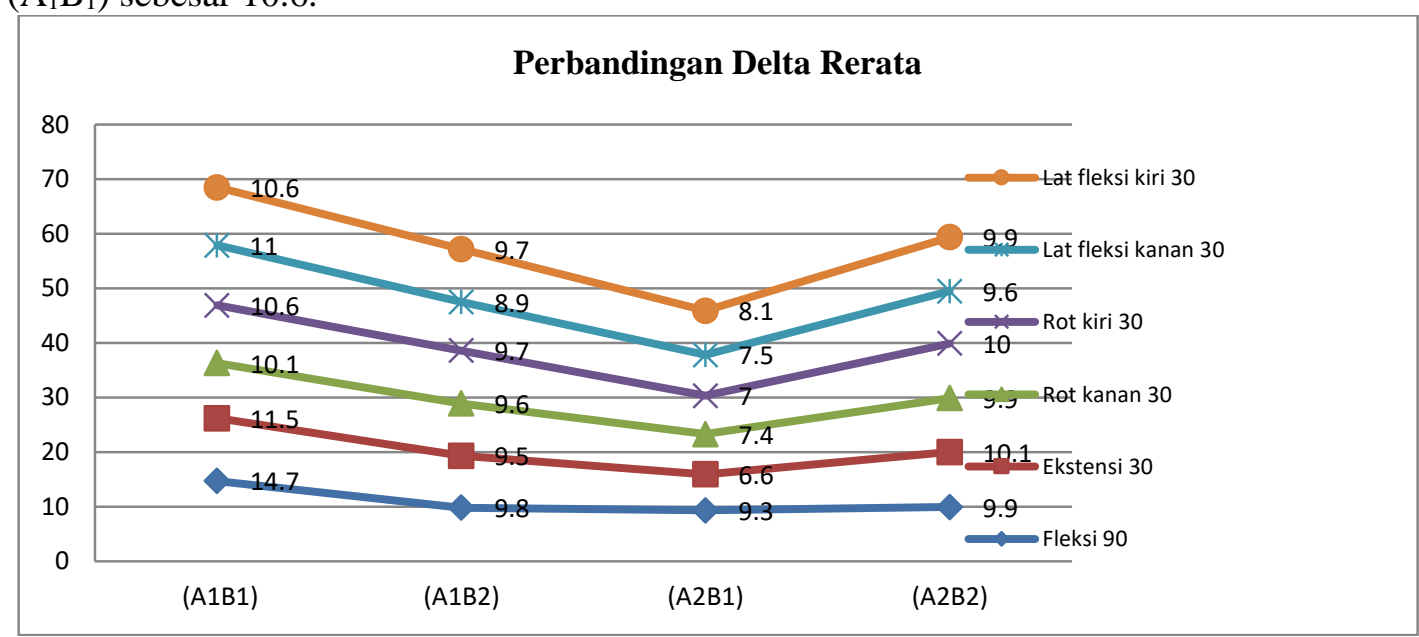

Gambar 6. Perbandingan Delta Rerata Masing-masing kelompok

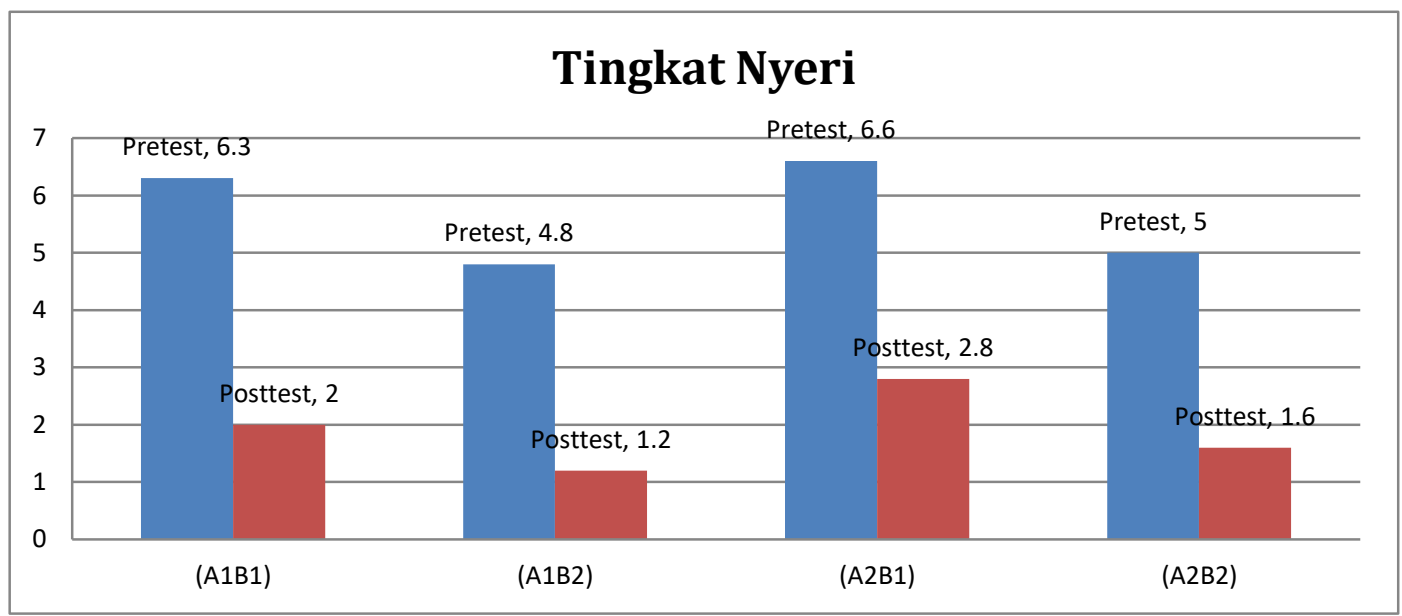

Gambar 7. Perbandingan Tingkat Nyeri Masing-masing kelompok

Tabel 10. Deskripsi Data Tingkat Nyeri Pada Masing-masing Kel. Perlakuan

\begin{tabular}{clccccc}
\hline No & Kel perlakuan & Rerata pretest & SD & Rerata posttest & SD & Penurunan \\
\hline 1 & $\left(\mathrm{~A}_{1} \mathrm{~B}_{1}\right)$ & 6,30 & 0,94 & 2,00 & 0,66 & 4,3 \\
2 & $\left(\mathrm{~A}_{1} \mathrm{~B}_{2}\right)$ & 4,80 & 0,78 & 1,20 & 0,42 & 3,6 \\
3 & $\left(\mathrm{~A}_{2} \mathrm{~B}_{1}\right)$ & 6,60 & 0,96 & 2,80 & 0,63 & 3,8 \\
4 & $\left(\mathrm{~A}_{2} \mathrm{~B}_{2}\right)$ & 5,00 & 0,81 & 1,60 & 0,69 & 3,4 \\
\hline
\end{tabular}




\section{Uji Normalitas}

Uji normalitas dilakukan untuk menguji apakah variabel yang dianalisis mempunyai sebaran data yang berdistribusi normal atau tidak. Uji normalitas data dilakukan menggunakan Kolmogorov Smirnov Z. Pembacaan hasil data dikatakan normal apabila $p$ value (Sig.) $>0,05$. Hasil uji normalitas ditunjukkan pada Tabel 11.

Fleksi

Tabel 11. Hasil Uji Normalitas Data Fleksi

\begin{tabular}{clccc}
\hline Kel & Pengamatan & KSZ & Sig. & Ket. \\
\hline \multirow{2}{*}{$\left(\mathrm{A}_{1} \mathrm{~B}_{1}\right)$} & Pretest & 0,685 & 0,737 & Normal \\
& Posttest & 0,684 & 0,737 & Normal \\
$\left(\mathrm{A}_{1} \mathrm{~B}_{2}\right)$ & Pretest & 0,611 & 0,849 & Normal \\
& Posttest & 0,461 & 0,984 & Normal \\
$\left(\mathrm{A}_{2} \mathrm{~B}_{1}\right)$ & Pretest & 0,549 & 0,924 & Normal \\
& Posttest & 0,702 & 0,709 & Normal \\
$\left(\mathrm{A}_{2} \mathrm{~B}_{2}\right)$ & Pretest & 0,683 & 0,739 & Normal \\
& Posttest & 0,580 & 0,889 & Normal \\
\hline
\end{tabular}

Hasil uji normalitas data fleksi kelompok $\mathrm{A}_{1} \mathrm{~B}_{1}$ saat pretest didapatkan nilai signifikan sebesar 0,737 dan saat posttest didapatkan nilai signifikan sebesar 0,737. Pada kelompok $\mathrm{A}_{1} \mathrm{~B}_{2}$ saat pretest didapatkan nilai signifikan sebesar 0,849 dan saat posttest didapatkan nilai signifikan sebesar 0,948. Pada kelompok $\mathrm{A}_{2} \mathrm{~B}_{1}$ saat pretest didapatkan nilai signifikansi sebesar 0,924 dan saat posttest didapatkan nilai signifikan sebesar 0,709. Pada kelompok $\mathrm{A}_{2} \mathrm{~B}_{2}$ saat pretest didapatkan nilai signifikan sebesar 0,739 dan saat posttest didapatkan nilai signifikan sebesar 0,889 .

Ekstensi

Tabel 12. Hasil Uji Normalitas Data Ekstensi

\begin{tabular}{clccc}
\hline Kel & Pengamatan & KSZ & Sig. & Ket. \\
\hline \multirow{2}{*}{$\left(\mathrm{A}_{1} \mathrm{~B}_{1}\right)$} & Pretest & 0,475 & 0,978 & Normal \\
& Posttest & 0,656 & 0,783 & Normal \\
$\left(\mathrm{A}_{1} \mathrm{~B}_{2}\right)$ & Pretest & 0,504 & 0,961 & Normal \\
& Posttest & 0,424 & 0,994 & Normal \\
$\left(\mathrm{A}_{2} \mathrm{~B}_{1}\right)$ & Pretest & 0,407 & 0,996 & Normal \\
& Posttest & 0,803 & 0,539 & Normal \\
$\left(\mathrm{A}_{2} \mathrm{~B}_{2}\right)$ & Pretest & 0,366 & 0,999 & Normal \\
& Posttest & 0,715 & 0,686 & Normal \\
\hline
\end{tabular}

Hasil uji normalitas data ekstensi kelompok $\mathrm{A}_{1} \mathrm{~B}_{1}$ saat pretest didapatkan nilai signifikan sebesar 0,978 dan saat posttest didapatkan nilai signifikansi sebesar 0,783. Pada kelompok $\mathrm{A}_{1} \mathrm{~B}_{2}$ saat pretest didapatkan nilai signifikan sebesar 0,961 dan saat posttest didapatkan nilai signifikan sebesar 0,994. Pada kelompok $\mathrm{A}_{2} \mathrm{~B}_{1}$ saat pretest didapatkan nilai signifikan sebesar 0,996 dan saat posttest didapatkan nilai signifikan sebesar 0,539. Pada kelompok $\mathrm{A}_{2} \mathrm{~B}_{2}$ saat pretest didapatkan nilai signifikan sebesar 0,999 dan saat posttest didapatkan nilai signifikan sebesar 0,686 .

\section{Rotasi Kanan}

Tabel 13. Hasil Uji Normalitas Data Rotasi Kanan

\begin{tabular}{clccc}
\hline Kel & Pengamatan & KSZ & Sig. & Ket. \\
\hline \multirow{2}{*}{$\left(\mathrm{A}_{1} \mathrm{~B}_{1}\right)$} & Pretest & 0,616 & 0,842 & Normal \\
& Posttest & 0,535 & 0,937 & Normal \\
$\left(\mathrm{A}_{1} \mathrm{~B}_{2}\right)$ & Pretest & 0,634 & 0,817 & Normal \\
& Posttest & 0,556 & 0,916 & Normal \\
$\left(\mathrm{A}_{2} \mathrm{~B}_{1}\right)$ & Pretest & 0,454 & 0,986 & Normal \\
& Posttest & 0,510 & 0,957 & Normal \\
$\left(\mathrm{A}_{2} \mathrm{~B}_{2}\right)$ & Pretest & 0,845 & 0,473 & Normal \\
& Posttest & 0,621 & 0,836 & Normal \\
\hline
\end{tabular}

Hasil uji normalitas data rotasi kanan kelompok $\mathrm{A}_{1} \mathrm{~B}_{1}$ saat pretest didapatkan nilai signifikan sebesar 0,842 dan saat posttest didapatkan nilai signifikan sebesar 0,937. Pada kelompok $\mathrm{A}_{1} \mathrm{~B}_{2}$ saat pretest didapatkan nilai signifikan sebesar 0,817 dan saat posttest didapatkan nilai signifikan sebesar 0,916. Pada kelompok $\mathrm{A}_{2} \mathrm{~B}_{1}$ saat pretest didapatkan nilai signifikan sebesar 0,986 dan saat posttest didapatkan nilai signifikansi sebesar 0,957. Pada kelompok $\mathrm{A}_{2} \mathrm{~B}_{2}$ saat pretest didapatkan nilai signifikan sebesar 0,473 dan saat posttest didapatkan nilai signifikan sebesar 0,836 .

\section{Rotasi Kiri}

Tabel 14. Hasil Uji Normalitas Data Rotasi Kiri

\begin{tabular}{llccc}
\hline Kel & Pengamatan & KSZ & Sig. & Ket. \\
\hline \multirow{2}{*}{$\left(\mathrm{A}_{1} \mathrm{~B}_{1}\right)$} & Pretest & 0,660 & 0,776 & Normal \\
& Posttest & 0,738 & 0,648 & Normal \\
$\left(\mathrm{A}_{1} \mathrm{~B}_{2}\right)$ & Pretest & 0,702 & 0,669 & Normal \\
& Posttest & 0,669 & 0,762 & Normal \\
$\left(\mathrm{A}_{2} \mathrm{~B}_{1}\right)$ & Pretest & 0,454 & 0,986 & Normal \\
& Posttest & 0,651 & 0,791 & Normal \\
$\left(\mathrm{A}_{2} \mathrm{~B}_{2}\right)$ & Pretest & 0,519 & 0,951 & Normal \\
& Posttest & 0,639 & 0,809 & Normal \\
\hline
\end{tabular}

Hasil uji normalitas data rotasi kiri kelompok $\mathrm{A}_{1} \mathrm{~B}_{1}$ saat pretest didapatkan nilai signifikan sebesar 0,776 dan saat posttest didapatkan nilai signifikan sebesar 0,684. Pada kelompok $\mathrm{A}_{1} \mathrm{~B}_{2}$ saat pretest didapatkan nilai signifikan sebesar 0,669 dan saat posttest didapatkan nilai signifikansi sebesar 0,762. Pada kelompok $\mathrm{A}_{2} \mathrm{~B}_{1}$ saat pretest didapatkan nilai signifikan sebesar 0,986 dan saat posttest didapatkan nilai signifikan sebesar 0,791. Pada kelompok $\mathrm{A}_{2} \mathrm{~B}_{2}$ saat pretest didapatkan nilai signifikan sebesar 0,951 dan saat 
posttest didapatkan nilai signifikan sebesar 0,809 .

\section{Lateral Fleksi Kanan}

Tabel 15. Hasil Uji Normalitas Data Lateral Fleksi Kanan

\begin{tabular}{lcccc}
\hline Kel & Pengamatan & KSZ & Sig. & Ket. \\
\hline \multirow{2}{*}{$\left(\mathrm{A}_{1} \mathrm{~B}_{1}\right)$} & Pretest & 0,416 & 0,995 & Normal \\
& Posttest & 0,529 & 0,942 & Normal \\
$\left(\mathrm{A}_{1} \mathrm{~B}_{2}\right)$ & Pretest & 0,561 & 0,911 & Normal \\
& Posttest & 0,695 & 0,720 & Normal \\
$\left(\mathrm{A}_{2} \mathrm{~B}_{1}\right)$ & Pretest & 0,507 & 0,959 & Normal \\
& Posttest & 0,523 & 0,947 & Normal \\
$\left(\mathrm{A}_{2} \mathrm{~B}_{2}\right)$ & Pretest & 0,447 & 0,988 & Normal \\
& Posttest & 0,509 & 0,958 & Normal \\
\hline
\end{tabular}

Hasil uji normalitas data lateral fleksi kanan kelompok $\mathrm{A}_{1} \mathrm{~B}_{1}$ saat pretest didapatkan nilai signifikan sebesar 0,995 dan saat posttest didapatkan nilai signifikan sebesar 0,942. Pada kelompok $\mathrm{A}_{1} \mathrm{~B}_{2}$ saat pretest didapatkan nilai signifikan sebesar 0,911 dan saat posttest didapatkan nilai signifikan sebesar 0,720. Pada kelompok $\mathrm{A}_{2} \mathrm{~B}_{1}$ saat pretest didapatkan nilai signifikan sebesar 0,959 dan saat posttest didapatkan nilai signifikan sebesar 0,947. Pada kelompok $\mathrm{A}_{2} \mathrm{~B}_{2}$ saat pretest didapatkan nilai signifikan sebesar 0,988 dan saat posttest didapatkan nilai signifikan sebesar 0,958.

\section{Lateral Fleksi Kiri}

Tabel 16. Hasil Uji Normalitas Data Lateral Fleksi Kiri

\begin{tabular}{ccccc}
\hline Kel & Pengamatan & KSZ & Sig. & Ket. \\
\hline \multirow{2}{*}{$\left(\mathrm{A}_{1} \mathrm{~B}_{1}\right)$} & Pretest & 0,697 & 0,717 & Normal \\
& Posttest & 0,544 & 0,929 & Normal \\
& Pretest & 0,811 & 0,526 & Normal \\
$\left(\mathrm{A}_{1} \mathrm{~B}_{2}\right)$ & Posttest & 0,654 & 0,786 & Normal \\
& Pretest & 0,405 & 0,997 & Normal \\
$\left(\mathrm{A}_{2} \mathrm{~B}_{1}\right)$ & Posttest & 0,490 & 0,970 & Normal \\
& Pretest & 0,447 & 0,998 & Normal \\
$\left(\mathrm{A}_{2} \mathrm{~B}_{2}\right)$ & Posttest & 0,893 & 0,403 & Normal \\
\hline
\end{tabular}

Hasil uji normalitas data lateral fleksi kiri kelompok $\mathrm{A}_{1} \mathrm{~B}_{1}$ saat pretest didapatkan nilai signifikan sebesar 0,717 dan saat posttest didapatkan nilai signifikan sebesar 0,929. Pada kelompok $\mathrm{A}_{1} \mathrm{~B}_{2}$ saat pretest didapatkan nilai signifikan sebesar 0,526 dan saat posttest didapatkan nilai signifikan sebesar 0,786. Pada kelompok $\mathrm{A}_{2} \mathrm{~B}_{1}$ saat pretest didapatkan nilai signifikan sebesar 0,997 dan saat posttest didapatkan nilai signifikan sebesar 0,970. Pada kelompok $\mathrm{A}_{2} \mathrm{~B}_{2}$ saat pretest didapatkan nilai signifikan sebesar 0,998 dan saat posttest didapatkan nilai signifikan sebesar 0,403.
Hasil analisis uji normalitas pada data pretest dan posttest pada masing-masing kelompok perlakuan didapatkan nilai signifikan lebih besar dari 0,05 $(p>0,05)$, maka data penelitian ini berdistribusi normal. Artinya sebaran data penelitian memenuhi kriteria kurva kenormalan data sebagai syarat analisis statistik parametrik.

\section{Uji Homogenitas}

Digunakan untuk menguji kesamaan varians data hasil pengamataan pada masingmasing kelompok perlakuan. Tes statistik yang digunakan untuk menguji homogenitas varians adalah uji-F. Pembacaan hasil data dikatakan homogen apabila $p$ value (sig.) $>0,05$. Hasil uji homogenitas ditunjukkan pada tabel 17.

Hasil Uji Homogenitas Pada Data Pretest

Tabel 17. Hasil Uji Homogenitas Data Pretest

\begin{tabular}{lccc}
\hline \multicolumn{1}{c}{ Variabel } & $\begin{array}{c}\mathrm{F} \\
\text { hitung }\end{array}$ & Sig. & Ket. \\
\hline Fleksi & 1,635 & 0,193 & Homogen \\
Ekstensi & 0,490 & 0,691 & Homogen \\
Rotasi kanan & 0,696 & 0,561 & Homogen \\
Rotasi kiri & 0,784 & 0,511 & Homogen \\
Lateral fleksi kanan & 0,423 & 0,738 & Homogen \\
Lateral fleksi kiri & 1,351 & 0,273 & Homogen \\
\hline
\end{tabular}

Berdasarkan hasil uji homogenitas pada Tabel 17 untuk menguji kesamaan varians hasil pengukuran data pada saat pre-test. Hasil uji homogenitas pada data fleksi, diperoleh nilai $\mathrm{F}$ hitung sebesar 1,635 dengan nilai signifikan sebesar 0,193. Pada data ekstensi, diperoleh nilai F hitung sebesar 0,490 dengan nilai signifikan sebesar 0,691. Pada data rotasi kanan, diperoleh nilai $F$ hitung sebesar 0,696 dengan nilai signifikan sebesar 0,561.

Pada data rotasi kiri, diperoleh nilai $\mathrm{F}$ hitung sebesar 0,784 dengan nilai signifikan sebesar 0,511. Pada data lateral fleksi kanan, diperoleh nilai $\mathrm{F}$ hitung sebesar 0,423 dengan nilai signifikansi sebesar 0,738 . Pada data lateral fleksi kiri, diperoleh nilai $\mathrm{F}$ hitung sebesar 1,351 dengan nilai signifikansi sebesar 0,273 . Oleh karena hasil uji homogenitas pada data pre-test didapatkan nilai signifikansi lebih besar dari 0,05 $(p>0,05)$, maka dapat dinyatakan bahwa data penelitian adalah homogen.

\section{Hasil Uji Homogenitas Pada Data Posttest}

Hasil uji homogenitas pada Tabel 18 untuk menguji kesamaan varians hasil pengukuran data pada saat post-test. Hasil uji homogenitas pada data fleksi, diperoleh nilai $\mathrm{F}$ hitung sebesar 1,093 dengan nilai signifikan sebesar 0,365 . Pada data 
ekstensi, diperoleh nilai $\mathrm{F}$ hitung sebesar 1,389 dengan nilai signifikan sebesar 0,262 . Pada data rotasi kanan, diperoleh nilai $\mathrm{F}$ hitung sebesar 0,700 dengan nilai signifikan sebesar 0,558.

Tabel 18. Hasil Uji Homogenitas Data Posttest

\begin{tabular}{lccc}
\hline \multicolumn{1}{c}{ Variabel } & F & Sig. & Ket. \\
\hline Fleksi & 1,093 & 0,365 & Homogen \\
Ekstensi & 1,389 & 0,262 & Homogen \\
Rotasi kanan & 0,700 & 0,558 & Homogen \\
Rotasi kiri & 1,217 & 0,318 & Homogen \\
Lateral fleksi kanan & 1,887 & 0,149 & Homogen \\
Lateral fleksi kiri & 1,247 & 0,343 & Homogen \\
\hline
\end{tabular}

Pada data rotasi kiri, diperoleh nilai $\mathrm{F}$ hitung sebesar 1,217 dengan nilai signifikan sebesar 0,318. Pada data lateral fleksi kanan, diperoleh nilai $\mathrm{F}$ hitung sebesar 1,887 dengan nilai signifikan sebesar 0,149 . Pada data lateral fleksi kiri, diperoleh nilai $\mathrm{F}$ hitung sebesar 1,247 dengan nilai signifikan sebesar 0,343. Oleh karena hasil uji homogenitas pada data post-test didapatkan nilai signifikan lebih besar dari 0,05 $(p>0,05)$, maka dapat dinyatakan bahwa data penelitian adalah homogen.

Pengujian Hipotesis

Pengujian hipotesis penelitian ini dilakukan dengan menggunakan analisis ANOVA dua jalur atau Two Way Anova. Hasil Uji Two Way Anova pada Tabel 19, menunjukkan perbandingan nilai rerata antar kelompok perlakukan. Tingkat kesembuhan nyeri pinggang dilihat dari ROM fleksi pada nyeri akut paling baik pada kelompok yang diberikan masase frirage yaitu sebesar 86,7. Tingkat kesembuhan nyeri pinggang dilihat dari ROM fleksi pada nyeri kronis paling baik pada kelompok yang diberikan kombinasi back masase stretching-nyeri kronis sebesar 78,6.Tingkat kesembuhan nyeri pinggang dilihat dari ROM ekstensi pada nyeri akut paling baik pada kelompok yang diberikan masase frirage yaitu sebesar 26,3. Tingkat kesembuhan nyeri pinggang dilihat dari ROM ekstensi pada nyeri kronis paling baik pada kelompok yang diberikan kombinasi back masase stretchingnyeri kronis sebesar 27,2.

Tingkat kesembuhan nyeri pinggang dilihat dari ROM rotasi kanan pada nyeri akut paling baik pada kelompok yang diberikan masase frirage yaitu sebesar 25,7. Tingkat kesembuhan nyeri pinggang dilihat dari ROM rotasi kanan pada nyeri kronis paling baik pada kelompok yang diberikan kombinasi back masase stretching-nyeri kronis sebesar 26,5. paling baik pada kelompok yang diberikan masase frirage yaitu sebesar 25,8.

Tabel 19. Hasil Analisis Statistik Uji Two Way Anova

\begin{tabular}{|c|c|c|c|}
\hline ROM & Kelompok perlakuan & Rerata & SD \\
\hline \multirow[t]{4}{*}{ Fleksi } & Masase frirage-nyeri akut & 86,8 & 2,09 \\
\hline & Masase frirage-nyeri kronis & 84,9 & 1,66 \\
\hline & Kombinasi back masase stretching-nyeri akut & 80,5 & 2,54 \\
\hline & Kombinasi back masase stretching-nyeri kronis & 87,6 & 1,89 \\
\hline \multirow[t]{4}{*}{ Ekstensi } & Masase frirage-nyeri akut & 26,3 & 2,58 \\
\hline & Masase frirage-nyeri kronis & 25,0 & 3,19 \\
\hline & Kombinasi back masase stretching-nyeri akut & 20,7 & 1,76 \\
\hline & Kombinasi back masase stretching-nyeri kronis & 27,2 & 2,48 \\
\hline \multirow[t]{4}{*}{ Rotasi kanan } & Masase frirage-nyeri akut & 25,7 & 1,76 \\
\hline & Masase frirage-nyeri kronis & 24,9 & 2,84 \\
\hline & Kombinasi back masase stretching-nyeri akut & 21,3 & 1,82 \\
\hline & Kombinasi back masase stretching-nyeri kronis & 26,5 & 1,90 \\
\hline \multirow[t]{4}{*}{ Rotasi kiri } & Masase frirage-nyeri akut & 25,8 & 2,39 \\
\hline & Masase frirage-nyeri kronis & 24,9 & 3,17 \\
\hline & Kombinasi back masase stretching-nyeri akut & 20,9 & 1,66 \\
\hline & Kombinasi back masase stretching-nyeri kronis & 26,6 & 2,31 \\
\hline \multirow[t]{4}{*}{ Lateral fleksi kanan } & Masase frirage-nyeri akut & 26,3 & 1,76 \\
\hline & Masase frirage-nyeri kronis & 25,9 & 2,02 \\
\hline & Kombinasi back masase stretching-nyeri akut & 22,2 & 2,48 \\
\hline & Kombinasi back masase stretching-nyeri kronis & 26,9 & 2,96 \\
\hline \multirow[t]{4}{*}{ Lateral fleksi kiri } & Masase frirage-nyeri akut & 26,6 & 1,83 \\
\hline & Masase frirage-nyeri kronis & 26,0 & 2,30 \\
\hline & Kombinasi back masase stretching-nyeri akut & 22,6 & 2,45 \\
\hline & Kombinasi back masase stretching-nyeri kronis & 27,2 & 1,68 \\
\hline
\end{tabular}


Jurnal Keolahragaan 7 (1), 2019 - 54

Ardi Utomo, BM. Wara Kushartanti

Tabel 20. Hasil Analisis Statistik Uji Two Way Anova

\begin{tabular}{llccc}
\hline \multicolumn{1}{c}{ Metode } & \multicolumn{1}{c}{ Variabel } & F hitung & Sig. & Ket. \\
\hline Jenis Perlakuan & Fleksi & 7,506 & 0,010 & Signifikan \\
& Ekstensi & 4,412 & 0,043 & Signifikan \\
& Rotasi kanan & 4,313 & 0,045 & Signifikan \\
& Rotasi kiri & 4,271 & 0,046 & Signifikan \\
& Lateral fleksi kanan & 4,335 & 0,044 & Signifikan \\
Kondisi cedera & Lateral fleksi kiri & 4,455 & 0,042 & Signifikan \\
& Fleks & & & \\
& Ekstensi & 15,660 & 0,000 & Signifikan \\
& Rotasi kanan & 10,321 & 0,003 & Signifikan \\
& Rotasi kiri & 10,650 & 0,002 & Signifikan \\
& Lateral fleksi kanan & 9,609 & 0,004 & Signifikan \\
Interaksi jenis perlakuan* & Lateral fleksi kiri & 8,341 & 0,007 & Signifikan \\
& Fleksi & 9,091 & 0,005 & Signifikan \\
& Ekstensi & & & \\
& Rotasi kanan & 46,911 & 0,000 & Signifikan \\
& Rotasi kiri & 23,221 & 0,000 & Signifikan \\
& Lateral fleksi kanan & 19,804 & 0,000 & Signifikan \\
& Lateral fleksi kiri & 18,167 & 0,000 & Signifikan \\
& & 1,734 & 0,002 & Signifikan
\end{tabular}

Tingkat kesembuhan nyeri pinggang dilihat dari ROM rotasi kiri pada nyeri akut Tingkat kesembuhan nyeri pinggang dilihat dari ROM rotasi kiri pada nyeri kronis paling baik pada kelompok yang diberikan kombinasi back masase stretching-nyeri kronis sebesar 26,6.

Tingkat kesembuhan nyeri pinggang dilihat dari ROM lateral fleksi kanan pada nyeri akut paling baik pada kelompok yang diberikan masase frirage yaitu sebesar 26,3. Tingkat kesembuhan nyeri pinggang dilihat dari ROM lateral fleksi kanan pada nyeri kronis paling baik pada kelompok yang diberikan kombinasi back masase stretching-nyeri kronis sebesar 26,9. Tingkat kesembuhan nyeri pinggang dilihat dari ROM lateral fleksi kiri pada nyeri akut paling baik pada kelompok yang diberikan masase frirage yaitu sebesar 26,6. Tingkat kesembuhan nyeri pinggang dilihat dari ROM rotasi lateral fleksi pada nyeri kronis paling baik pada kelompok yang diberikan kombinasi back masase stretching-nyeri kronis sebesar 27,2.

Pengujian Hipotesis Pertama

Hipotesis pertama dalam penelitian ini menyatakan bahwa terdapat pengaruh jenis perlakuan massage frirage dan kombinasi back massage-streaching untuk penyembuhan nyeri pinggang yang ditunjukkan peningkatan ROM pinggang pada pasien Physical Therapy Clinic FIK UNY. Hasil analisis analisis statistik uji Two Way Anova pada data ROM Tabel 20 dapat dilihat hasil perlakuan massage frirage dan kombinasi back massage-stretching diketahui pada data fleksi, ekstensi, rotasi kanan, rotasi kiri, lateral fleksi kanan dan lateral fleksi kiri semuanya signifikan dikarenakan nilai signifikan hasil analisis Two Way Anova pada data ROM lebih kecil dari 0,05 $(p<0,05)$, maka dapat disimpulkan terdapat pengaruh jenis perlakuan massage frirage dan kombinasi back massage-stretching untuk penyembuhan nyeri pinggang yang ditunjukkan peningkatan ROM pinggang pada pasien Physical Therapy Clinic FIK UNY, sehingga hipotesis pertama penelitian ini dapat diterima.

\section{Pengujian Hipotesis Kedua}

Hipotesis kedua dalam penelitian ini menyatakan bahwa terdapat pengaruh kondisi cedera akut dan kronis terhadap penyembuhan nyeri pinggang yang ditunjukkan peningkatan ROM pinggang pada pasien Physical Therapy Clinic FIK UNY. Hasil analisis yang terdapat pada Tabel 20 dengan menggunakan statistik uji Two Way Anova bahwa pada data perbedaan tingkat nyeri akut dan kronis pada pengamatan ROM fleksi, ekstensi, rotasi kanan, rotasi kiri, lateral fleksi kanan, lateral fleksi kiri semuanya signifikan dan hasil analisis pada data tingkat nyerti didapatkan nilai $F$ sebesar 26,471 dengan nilai signifikansi 0,000 . Oleh karena nilai signifikan hasil analisis Two Way Anova pada data ROM lebih kecil dari 0,05 ( $p<0,05)$, maka dapat disimpulkan terdapat pengaruh kondisi cedera 
akut dan kronis terhadap penyembuhan nyeri pinggang yang ditunjukkan peningkatan ROM pinggang pada pasien Physical Therapy Clinic FIK UNY, sehingga hipotesis kedua penelitian ini dapat diterima.

Pengujian Hipotesis Ketiga

Hipotesis ketiga dalam penelitian ini menyatakan bahwa terdapat interaksi jenis perlakuan dengan kondisi cedera terhadap penyembuhan nyeri pinggang yang ditunjukkan peningkatan ROM pinggang pada pasien Physical Therapy Clinic FIK UNY. Hasil pada tabel 20 dalam analisis statistik uji Two Way Anova pada data pengamatan ROM fleksi, ekstensi, rotasi kanan, rotasi kiri, lateral fleksi kanan, lateral fleksi kiri semuannya signifikan dengan nilai signifikansi 0,000. Oleh karena nilai signifikansi hasil analisis Two Way Anova pada data ROM lebih kecil dari $0,05 \quad(p<0,05)$, maka dapat disimpulkan terdapat interaksi jenis perlakuan dengan kondisi cedera terhadap penyembuhan nyeri pinggang yang ditunjukkan pening-katan ROM sehingga hipotesis ketiga penelitian ini dapat diterima.

\section{SIMPULAN}

Berdasarkan hasil analisis data dan pembahasan yang telah dilakukan, penelitian ini dapat disimpulkan bahwa, Pertama terdapat pengaruh jenis perlakuan massage frirage dan kombinasi back massage-streaching untuk penyembuhan nyeri pinggang yang ditunjukkan peningkatan ROM pinggang pada pasien Physical Therapy Clinic FIK UNY. Terapi masase frirage lebih baik dalam menyembuhkan nyeri pinggang dibandingkan dengan kombinasi back massage-stretching. Kedua, terdapat pengaruh kondisi cedera akut dan kronis terhadap penyembuhan nyeri pinggang yang ditunjukkan peningkatan ROM pinggang pada pasien Physical Therapy Clinic FIK UNY. Pasien nyeri kronis lebih cepat sembuh, karena merupakan nyeri lama yang kambuh kembali dibandingkan dengan pasien nyeri akut yang merupakan nyeri baru. Ketiga, terdapat interaksi jenis perlakuan dengan kondisi cedera terhadap penyembuhan nyeri pinggang yang ditunjukkan peningkatan ROM pinggang pada pasien Physical Therapy Clinic FIK UNY. Hasil analisis diketahui masase frirage lebih baik untuk menyembuhkan nyeri pinggang akut sedangkan kombinasi back massage-stretching lebih baik untuk menyembuhkan nyeri pinggang kronis yang terindikasi peningkatan pada ROM pinggang.

\section{DAFTAR PUSTAKA}

Arovah, N. I. (2010). Dasar-dasar fisioterapi pada cedera olahraga. Yogyakarta: Universitas Negeri Yogyakarta.

Graha, A. S., \& Priyonoadi, B. (2009). Terapi masase frirage penatalaksanaan cedera pada anggota tubuh bagian atas. Yogyakarta: Universitas Negeri Yogyakarta.

Graha, A. S., \& Priyonohadi, B. (2012). Terapi masase frirage penatalaksanaan cedera pada anggota gerak tubuh bagian bawah. Yogyakarta: Universitas Negeri Yogyakarta.

Jennifer, H., \& Saptutyningsih, E. (2015). Preferensi individu terhadap pengobatan tradisional di Indonesia. Jurnal Ekonomi \& Studi Pembangunan, 16(1), 26-41. https://doi.org/10.18196/jesp.2015.0039.26 $-41$

Kallewaard, J. W., Terheggen, M. a, Groen, G. J., Sluijter, M. E., Derby, R., Kapural, L., ... van Kleef, M. (2010). Evidence-based interventional pain medicine. 15 . Discogenic low back pain. Pain Pract, 10(6), 560-579. https://doi.org/10.1111/j.15332500.2010.00408.x

Kambodji, J. (2002). Pengaruh intensitas nyeri terhadap keterbatasan fungsional aktivitas sehari-hari penderita nyeri punggung bawah kronis. Universitas Gadjah Mada.

Lestari, N. L. P. S. M., Sukarja, I. M., \& Suari, W. (2018). Pengaruh stretching terhadap keluhan muskuloskeletal pada perawat. COPING (Community of Publishing in Nursing), 2(3). Retrieved from https://ojs.unud.ac.id/index.php/coping/arti cle/view/10766

Presiden Republik Indonesia. Undang-undang Republik Indonesia nomor 23 tahun 1992 tentang kesehatan, Pub. L. No. 23 (1992). Indonesia.

Presiden Republik Indonesia. Undang-undang Republik Indonesia nomor 10 tahun 2009 tentang kepariwisataan, Pub. L. No. 10 (2009). Indonesia.

Presiden Republik Indonesia. Peraturan Pemerintah Republik Indonesia nomor 52 tahun 2012 tentang sertifikasi kompetensi dan sertifikasi usaha di bidang pariwisata (2012). Indonesia. 
Jurnal Keolahragaan 7 (1), 2019 - 56

Ardi Utomo, BM. Wara Kushartanti

Sugiharto, F. B., Supriyono, S., \& Rasyad, A. (2016). Transfer of knowledge keterampilan pengobatan tradisional Pijat Sangkal Putung. Jurnal Pendidikan: Teori, Penelitian, Dan Pengembangan, 1(9), 1864-1868.

https://doi.org/10.17977/JP.V1I9.6862

Syafi'i, A. (2019). Pengaruh terapi masase, masase dengan yoga, dan masase dengan meditasi terhadap penurunan tekanan darah dan tingkat kecemasan pada penderita hipertensi. Massage for Sport Therapy and Injury, 1(1), 18-29.

https://doi.org/10.26486/MASTRI.V1I1.10

Tana, L., \& Delima, D. (2013). Gambaran nyeri pinggang pada paramedis di beberapa rumah sakit di Jakarta. Media Penelitian Dan Pengembangan Kesehatan, 23(1), 17. Retrieved from http://ejournal.litbang.depkes.go.id/index.p $\mathrm{hp} / \mathrm{MPK} /$ article/view/3059 